\title{
Endoparasites of household and shelter cats in the city of Rio de Janeiro, Brazil
}

\author{
Endoparasitos de gatos domiciliados e de abrigos da cidade do Rio \\ de Janeiro, Brasil \\ Nilcéia de Veiga Ramos* (1); Monique Lourenço e Silva'; Marília Senra Barreto; \\ Luciano Antunes Barros²; Flavya Mendes-de-Almeida ${ }^{1}$ \\ ${ }^{1}$ Departamento de Clínica e Patologia Veterinária, Faculdade de Veterinária, Universidade Federal Fluminense - UFF, \\ Niterói, RJ, Brasil \\ ${ }^{2}$ Departamento de Saúde Coletiva e Saúde Pública Veterinária - MSV, Faculdade de Veterinária, Universidade Federal \\ Fluminense - UFF, Niterói, RJ, Brasil
}

How to cite: Ramos NV, Lourenço e Silva M, Barreto MS, Barros LA, Mendes-de-Almeida F. Endoparasites of household and shelter cats in the city of Rio de Janeiro, Brazil. Braz J Vet Parasitol 2020; 29(1): e012819. https://doi.org/10.1590/S1984-29612019110.

\begin{abstract}
Endoparasitic infections are associated with morbidity in cats. This study aimed to investigate the occurrence of endoparasites among cats of different life stages in the city of Rio de Janeiro, Brazil. The samples were analyzed individually by macroscopic exploration for proglottids and centrifugal-flotation. Stool samples were obtained from household cats $(n=57)$ and shelter cats $(n=336)$. Endoparasites were detected in $50.64 \%$ of the samples. Among household and shelter cats, $21.05 \%$ and $55.66 \%$ were infected with endoparasites, respectively. In household cats, the most prevalent endoparasites were Ancylostoma spp. (in 25.0\%) and Strongyloides spp. (in 25.0\%), followed by Toxocara spp. (in 16.67\%), Dipylidium caninum (in 16.67\%), Cystoisospora spp. (in 8.33\%), and Uncinaria spp. + Ancylostoma spp. (in 8.33\%). In shelter cats, the most prevalent endoparasite was Ancylostoma spp. (in 29.41\%), followed by Cystoisospora spp. (in 26.20\%) and Toxocara spp. (in 16.58\%), as well as Cystoisospora spp. + Toxocara spp. (in 8.02\%); Ancylostoma spp. + Toxocara spp. (in 11.76\%); Cystoisospora spp. + Ancylostoma spp. (in 3.74\%); Cystoisospora spp. + Toxocara spp. + Ancylostoma spp. (in 3.21\%); and Dipylidium caninum + Ancylostoma spp. (in 0.53\%). Endoparasitic infections in cats underscore the need for preventive veterinary care and routine coproparasitologic tests.
\end{abstract}

Keywords: Feline, parasites, helminths, protozoan, feces, lungworms.

\section{Resumo}

Endoparasitoses estão associadas à morbidade em gatos. Este estudo objetivou investigar a ocorrência de endoparasitos em gatos de diversas faixas etárias, na cidade do Rio de Janeiro. As amostras passaram por exploração macroscópica à procura de proglotes de cestódeos e analisadas individualmente por centrífugo-flutuação. Assim, amostras fecais foram obtidas de gatos domiciliados $(n=57$ ) e de abrigos $(n=336$ ). Endoparasitos foram detectados em $50,64 \%$ das amostras fecais. Nos gatos domiciliados e de abrigos, $21,05 \%$ e 55,66\% estavam infectados por endoparasitos, respectivamente. Ancylostoma spp. (25\%) e Strongyloides spp. (25\%) foram os 
helmintos mais prevalentes encontrados nas amostras de fezes dos gatos domiciliados, seguido por Toxocara spp. (16,67\%), Dypilidium caninum (16,67\%), Cystoisospora spp. (8,33\%) e a associação de Uncinaria spp. e Ancylostoma spp. (8,33\%). Entre os gatos dos abrigos, Ancylostoma spp. estavam presentes em 29,41\% das amostras, seguidos por Cystoisospora spp. (26,20\%), Toxocara spp. (16,58\%) e as associações de parasitos Cystoisospora spp. + Toxocara spp. (8,02\%), Ancylostoma spp. + Toxocara spp. (11,76\%), Cystoisospora spp. + Ancylostoma spp (3,74\%), Cystoisospora spp. + Toxocaraspp. + Ancylostoma spp. (3,21\%) e Dipylidium caninum + Ancylostoma spp. (0,53\%). Cystoisospora spp. foi o único protozoário encontrado. A presença de endoparasitos reforça a necessidade de cuidados veterinários preventivos e testes coproparasitológicos de rotina para evitar sua disseminação.

Palavras-chave: Felinos, parasitos, helmintos, protozoários, fezes, vermes pulmonares.

\section{Introduction}

Pet ownership has been shown to help improve the physical and mental health of humans (Matchock, 2015). The emotional bond that forms between humans and their companion animals can be compared to that occurring in many human relationships and may confer similar psychological benefits (McNicholas et al., 2005). Given the closeness between cats and humans, the greater importance of cats as pets, the potential for endoparasites to cause morbidity in cats (Yang \& Liang, 2015), and the fact that felines can be hosts to parasites with zoonotic potential (Villeneuve et al., 2015), knowledge of the regional prevalence of endoparasites in domestic cats has major implications for the welfare of humans and felines alike (Ito et al., 2016).

Hookworms (e.g., Ancylostoma spp.) are the most common parasites, causing infection in cats and potentially causing cutaneous larva migrans in humans (Bowman et al., 2010). In a study conducted by Pereira et al. (2017), involving stray and shelter cats in the city of Rio de Janeiro, located in the southeastern region of Brazil, the proportions of cats infected with hookworms were $87.9 \%$ and $93.3 \%$, respectively.

Ascarids (e.g., Toxocara spp.) are the causative agents of ocular and visceral larva migrans (Fisher, 2003). Toxocariasis is considered one of the most pathogenic helminth infections and one of the major neglected illnesses in the United States (Hotez, 2008). In a necropsy study conducted in the city of Cuiabá, in the central-west region of Brazil, Ramos et al. (2013) found the prevalence of toxocariasis in cats to be $4.4 \%$, whereas Pereira et al. (2017) found it to be $2.2 \%$ in stool samples collected from shelter and stray cats in the city of Rio de Janeiro.

Another helminth commonly detected in cat feces is the tapeworm Dipylidium caninum. Infection with $D$. caninum, which primarily affects infants and children, causes discomfort, diarrhea, and pruritus (Jiang et al., 2017). Children are the most exposed population because they are more likely to come into contact with pets, and therefore, are more likely to ingest fleas harboring the cysticercoids (Bowman et al., 2002a; Blaszkowska et al., 2013). Gennari et al. (2016) analyzed stool samples from cats in the metropolitan region of São Paulo and found a $0.4 \%$ prevalence of dipylidiasis. Pereira et al. (2017) found the prevalence of dipylidiasis to be $2.2 \%$ and $6.7 \%$ among stray and shelter cats, respectively, in the city of Rio de Janeiro. Monteiro et al. (2016) identified dipylidiasis in $0.88 \%$ of stool samples collected from household cats in the northeastern region of the country.

Nematodes of the genus Strongyloides are the only worms in the order Rhabditida that infect cats. The adult females are parthenogenetic and invade the epithelium of the 
intestinal mucosa of their hosts (Bowman, 2014). In one study, infection with Strongyloides sp. was identified in $21.23 \%$ of household cats in the northeastern region of Brazil (Monteiro et al., 2016).

Enteric parasites, such as the metastrongylid nematodes of the genus Aelurostrongylus also cause morbidity in cats (Traversa \& Guglielmini, 2008; Traversa \& Di Cesare, 2013). Aelurostrongylus abstrusus is the most well-known nematode infecting the respiratory tract of the cat, its natural host (Traversa et al., 2010). The lifestyle of cats influences the occurrence of aelurostrongylosis (Elsheikha et al., 2016). There have been a few studies of aelurostrongylosis among cats in the city of Rio de Janeiro. In one such study, reported one case of $A$. abstrusus infection in a cat that died from respiratory complications, diagnosed by histopathology (Scofield et al., 2005). Using the Baermann technique, Souza-Dantas (2006) analyzed 546 feline stool samples and found a 3.7\% prevalence of aelurostrongylosis. Ferreira et al. (2007) reported the diagnosis of $A$. abstrusus in a cat at necropsy. These data indicate the need to include aelurostrongylosis as a differential diagnosis in the veterinary medicine routine (Ferreira et al., 2007).

In addition to helminths, protozoan species such as Cystoisospora spp. often cause morbidity in cats, especially kittens (Petry et al., 2011). Nevertheless, the species of the genus Cystoisospora that infect cats are not a public health concern. In Brazil, data related to cats in the state of Pernambuco showed a prevalence of $25.6 \%$ for infection with Cystoisospora sp (Monteiro et al., 2016). In the city of São Paulo, the reported prevalence of such infection ranges from 4.6\% (Gennari et al., 2016) to 43.1\% (Coelho et al., 2009), whereas, in the city of Rio de Janeiro, it ranges from 16.5\% (Pereira et al., 2017) to $43.5 \%$ (Serra et al., 2003).

Having an understanding of the local prevalence of parasitic diseases allows physicians and veterinarians to promote public awareness and take appropriate actions to control parasites for the benefit of people and pets (Knaus et al., 2014). Therefore, the objective of the present study was to investigate the occurrence of endoparasitic infections in household and shelter cats.

\section{Material and Methods}

\section{Study design}

Stool samples were obtained by convenience sampling from household and shelter cats (of both sexes, any breed, any age, and any reproductive status) in various zones of the city of Rio de Janeiro: southern, northern, western, and downtown. A questionnaire was completed for each cat. The age groups were defined, in accordance with the Feline Life Stage Guidelines established by the American Association of Feline Practitioners and the American Animal Hospital Association (Hoyumpa Vogt et al., 2010), as follows: birth to 6 months (kitten); 7 months to 2 years (junior); 3-6 years (prime); 7-10 years (mature); 11-14 years (senior); and $\geq 15$ years (geriatric). All procedures involving animals were performed in accordance with the guidelines established by the Animal Experimentation Ethics Committee (Permit no. 877) of the Universidade Federal Fluminense, located in the city of Niterói, Rio de Janeiro, Brazil. 


\section{Household cats}

Household 57 cats were fed commercial cat food and had ad libitum access to drinking water and litter boxes. These cats had either a confined lifestyle (i.e., were not allowed to leave the domicile) or a semi-confined lifestyle (i.e., were allowed access to the outdoors).

\section{Shelter cats}

Shelter 336 cats were fed commercial cat food and had access to drinking water that was managed by handlers daily. These cats had access either to litter boxes (southern zone shelter) or to trays covered with newspaper (western, northern, and downtown zone shelters). They had either a confined lifestyle (in individual cages), a semi-confined lifestyle (with access to the outdoors), or a free-roaming lifestyle. Those that had entered the shelter less than one month before the study were also considered to have a free-roaming lifestyle.

\section{Collecting samples}

The stool samples were collected individually from fresh deposits in litter boxes, placed in sterile universal collectors, and refrigerated at $8^{\circ} \mathrm{C}$ until processing, which occurred on the same day at the Laboratory of Diagnostic Support in Parasitic Diseases of the Universidade Federal Fluminense School of Veterinary Medicine.

\section{Fecal analysis}

In the laboratory, the samples were explored macroscopically for cestode proglottids, processed and analyzed individually by centrifugal-flotation in saturated sugar solution, as previously described (Sheather, 1923). The same operator processed all the samples the same day they were collected. For the study of pulmonary helminths, the Baermann-Moraes technique was used (Bowman et al., 2014). Using a binocular light microscope (CX22; Olympus, Tokyo, Japan), we analyzed slides at a magnification of $100 \times$ and, if necessary, confirmed our findings at a magnification of $400 \times$. The taxonomic identification of the parasites was based on established morphometric parameters (Bowman et al., 2002b).

\section{Statistical analysis}

The data obtained were compiled, and statistical significance was determined by chi-square test or Fisher's exact test, as appropriate. The statistical analysis was performed with Epi Info, version 3.5.2 (CDC, 2011). The level of statistical significance was set at 5\%.

\section{Results}

Of the 57 household cats, $31(54.39 \%)$ were female $(p=0.450)$. As shown in Table 1, ten of the household cats were adults of undetermined age. Among the remaining 47 cats, the life stage was classified as junior in 17 (36.17\%), prime in $13(27.65 \%)$, and mature in nine $(19.15 \%)$, the differences being significant $(p \leq 0.001)$. As can also be seen in Table 1, 36 (63.16\%) of the 57 household cats had a confined lifestyle and 21 (36.84\%) had a semi-confined lifestyle $(p \leq 0.008) ; 51(89.47 \%)$ were in the western zone of the city, five $(8.77 \%)$ were in the northern zone, and one $(1.75 \%)$ was in the southern zone $(p \leq 0.001)$. 
Table 1. Characteristics of the household cats evaluated*.

\begin{tabular}{|c|c|}
\hline Characteristic & $(N=57)$ \\
\hline \multicolumn{2}{|l|}{ Sex, $n(\%)$} \\
\hline Male & $26(45.61)$ \\
\hline Female & 31 (54.39) \\
\hline \multicolumn{2}{|l|}{ Life stage, $n(\%)^{\dagger}$} \\
\hline Kitten & $5(10.64)^{a}$ \\
\hline Junior & $17(36.17)^{b}$ \\
\hline Prime & $13(27.65)^{b}$ \\
\hline Mature & $9(19.15)^{b}$ \\
\hline Senior & $1(2.13)^{a}$ \\
\hline Geriatric & $2(3.51)^{a}$ \\
\hline \multicolumn{2}{|l|}{ Lifestyle, $n(\%)$} \\
\hline Confined & $36(63.16)^{a}$ \\
\hline Semi-confined & $21(36.84)^{b}$ \\
\hline \multicolumn{2}{|l|}{ Zone of the city, $n(\%)$} \\
\hline Northern & $5(8.77)^{a}$ \\
\hline Southern & $1(1.75)^{a}$ \\
\hline Western & $51(89.47)^{\mathrm{b}}$ \\
\hline \multicolumn{2}{|c|}{$\begin{array}{l}\text { *Different letters in each category indicate significance }(p \leq 0.05) .{ }^{\dagger} 10 \text { cats were of undetermined age (i.e., } N=47 \\
\text { for this category). }\end{array}$} \\
\hline \multicolumn{2}{|c|}{$\begin{array}{l}\text { Of the } 336 \text { shelter cats, } 174(51.78 \%) \text { were female }(p=0.396) \text {. As shown in Table } 2,22 \text { of the } \\
\text { shelter cats were adults of undetermined age. Among the remaining } 314 \text { cats, the life stage was } \\
\text { classified as kitten in } 155(49.36 \%) \text {, junior in } 87(27.71 \%) \text {, and prime in } 64(20.38 \%) \text {, the difference } \\
\text { between the kitten stage and the other stages being significant }(p \leq 0.001) \text {. As also shown in } \\
\text { Table } 2,90(27.79 \%) \text { of the } 336 \text { shelter cats had a confined lifestyle, } 38(11.31 \%) \text { had a semi- } \\
\text { confined lifestyle, and } 208(61.90 \%) \text { had a free-roaming lifestyle }(p \leq 0.001) \text {. The shelter cats were } \\
\text { all of mixed breed and had been abandoned or rescued from the streets. Of the } 336 \text { shelter } \\
\text { cats, } 81 \text { ( } 24.11 \%) \text { were at one of two shelters in the northern zone, } 159(47.32 \%) \text { were at a } \\
\text { shelter in the southern zone ( } p \leq 0.001 \text { vs. the northern zone), } 45(13.39 \%) \text { were at one of two } \\
\text { shelters in the western zone, and } 51(15.18 \%) \text { were at a shelter in the downtown zone. }\end{array}$} \\
\hline
\end{tabular}

Table 2. Characteristics of the shelter cats evaluated*.

\begin{tabular}{lc}
\hline \multicolumn{1}{c}{ Characteristic } & $(\boldsymbol{N}=\mathbf{3 3 6})$ \\
\hline Sex, $\boldsymbol{n}(\%)$ & $162(48.21)$ \\
Male & $174(51.79)$ \\
Female & \\
Life stage, $\boldsymbol{n}(\%)^{\dagger}$ & $155(49.36)^{\mathrm{a}}$ \\
Kitten & $87(27.70)^{\mathrm{b}}$ \\
Junior & $64(20.38)^{\mathrm{b}}$ \\
Prime & $4(1.27)^{\mathrm{c}}$ \\
Mature & $3(0.95)^{\mathrm{c}}$ \\
Senior & $1(0.32)^{\mathrm{c}}$ \\
Geriatric & \\
Lifestyle, $\boldsymbol{n}(\%)$ & $90(26.79)^{\mathrm{a}}$ \\
Confined & $38(11.31)^{\mathrm{b}}$ \\
Semi-confined & $208(61.90)^{\mathrm{c}}$ \\
Free-roaming & \\
Zone of the city, $\boldsymbol{n}(\%)$ & $81(24.11)^{\mathrm{a}}$ \\
Northern & $159(47.32)^{\mathrm{b}}$ \\
Southern & $45(13.39)^{\mathrm{c}}$ \\
Western & $51(15.18)^{\mathrm{c}}$ \\
Downtown &
\end{tabular}

*Different letters in each category indicate significance $(p \leq 0.05) .{ }^{\dagger} 22$ cats were of undetermined age $(N=314$ for this category). 
As can be seen in Table 3, endoparasites were detected in 199 (50.64\%) of the 393 stool samples collected. Of the 57 household cats, $12(21.05 \%)$ were infected with at least one gastrointestinal parasite (Figure 1), compared with $187(55.66 \%)$ of the 336 shelter cats $(p \leq 0.001)$ (Figure 2$)$. The prevalence of endoparasite infection was significantly higher among the shelter cats than among the household cats, for female and male cats ( $p \leq 0.05$ for both). The only life stage for which gastrointestinal infection showed a statistically significant difference between the shelter cats and the household cats was the prime stage $(p=0.01599)$. Among the cats of undetermined age, endoparasite infection was identified in three $(30.0 \%)$ of the 10 that were household cats and in $12(54.54 \%)$ of the 22 that were shelter cats. Among the cats with a confined lifestyle, there was a statistically significant difference between the household and shelter cats in terms of the prevalence of endoparasite infection $(p=0.02140)$. Endoparasite infection was identified in six $(28.57 \%)$ of the 21 household cats with a semi-confined lifestyle, compared with 20 (52.63\%) of the shelter cats with that lifestyle, although the difference between the two groups was not statistically significant $(p=0.3267)$. Among the 208 cats with a free-roaming lifestyle (shelter cats only), endoparasite infection was identified in 131 (62.98\%). The zone of the city in which a cat lived had no significant effect on the prevalence of endoparasite infection for the household cats $(p=0.1273)$, although there was a significant difference among the zones for the shelter cats, for which the prevalence was $61.73 \%$ in the northern zone, $59.75 \%$ in the southern zone, $50.98 \%$ in the downtown zone and $35.56 \%$ in the western zone $(p=0.008)$. The overall prevalence of endoparasite infection was $50.64 \%$, being $21.05 \%$ among the household cats and $55.66 \%$ among the shelter cats.

Table 3. Endoparasite infection, by group, among cats in the city of Rio de Janeiro, Brazil*.

\begin{tabular}{|c|c|c|}
\hline \multirow{2}{*}{ Characteristic } & \multicolumn{2}{|c|}{ Endoparasite infection } \\
\hline & Household cats & Shelter cats \\
\hline \multicolumn{3}{|l|}{ Sex, $n / N(\%)$} \\
\hline Male & $7 / 26(26.92)^{a}$ & $84 / 162(51.85)^{\mathrm{b}}$ \\
\hline Female & $5 / 31(16.13)^{a}$ & $103 / 174(59.19)^{b}$ \\
\hline \multicolumn{3}{|l|}{ Life stage, $n / N(\%)$} \\
\hline Kitten & $2 / 5(40.0)$ & $98 / 155(63.22)$ \\
\hline Junior & $5 / 17(29.41)$ & $42 / 87(48.27)$ \\
\hline Prime & $1 / 13(7.69)^{a}$ & $31 / 64(48.44)^{b}$ \\
\hline Mature & $1 / 9(11.11)$ & $2 / 4(50.0)$ \\
\hline Senior & $-/ 1(-)$ & $1 / 3(33.33)$ \\
\hline Geriatric & $-/ 2(-)$ & $1 / 1(100)$ \\
\hline Undetermined & $3 / 10(30.0)$ & $12 / 22(54.54)$ \\
\hline \multicolumn{3}{|l|}{ Lifestyle, $n / N(\%)$} \\
\hline Confined & $6 / 36(16.67)^{a}$ & $36 / 90(40.0)^{b}$ \\
\hline Semi-confined & $6 / 21(28.57)$ & $20 / 38(52.63)$ \\
\hline Free-roaming & - & $131 / 208(62.98)$ \\
\hline \multicolumn{3}{|l|}{ Zone of the city, $n / N(\%)$} \\
\hline Northern & $1 / 5(20.0)$ & $50 / 81(61.73)$ \\
\hline Southern & $1 / 1(100)$ & $95 / 159(59.75)$ \\
\hline Western & $10 / 51(19.61)$ & $16 / 45(35.56)$ \\
\hline Downtown & $0 / 0(-)$ & $26 / 51(50.98)$ \\
\hline
\end{tabular}

*Different letters in each category indicate significance $(p \leq 0.05)$. 


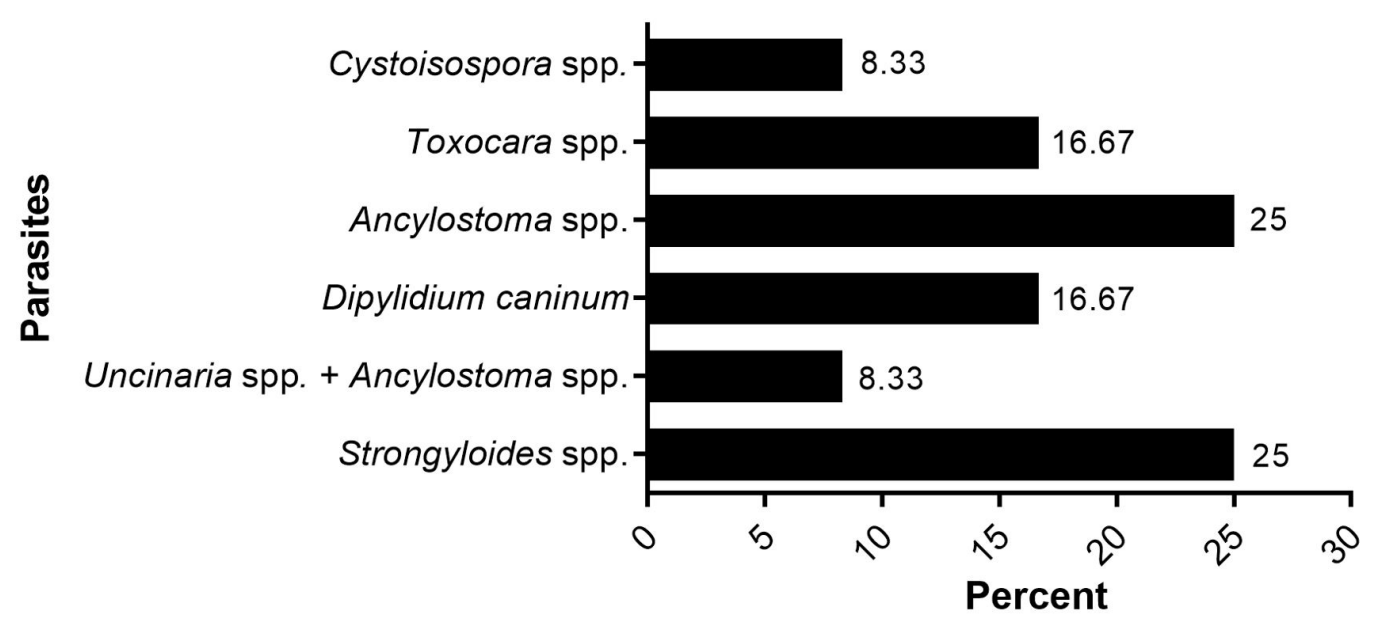

Figure 1. Prevalence of intestinal parasites among household cats in the city of Rio de Janeiro, Brazil ( $n=57$ cats).

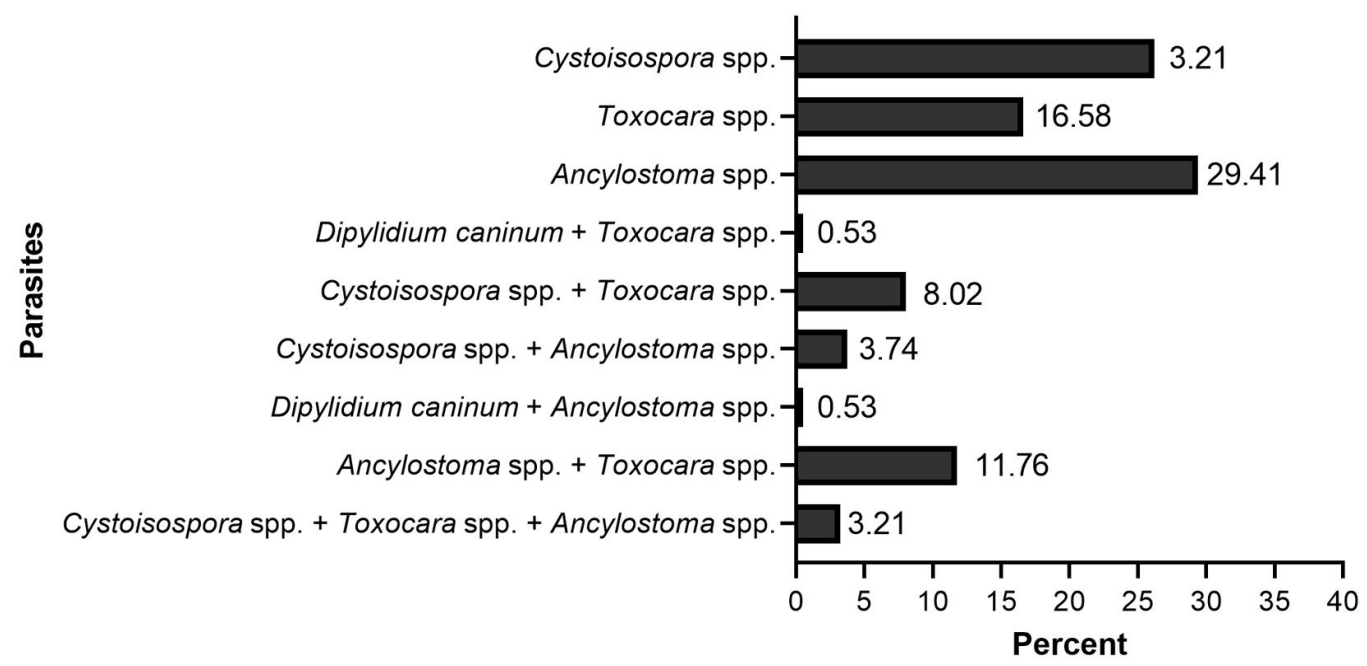

Figure 2. Prevalence of intestinal parasites among shelter cats in the city of Rio de Janeiro, Brazil ( $n=336$ cats).

As shown in Table 4, the most common parasites in the household cats were helminths, especially those of the genera Ancylostoma and Strongyloides, each of which was identified in three (25.0\%) of the 12 infected cats, followed by Toxocara spp. and Dipylidium caninum identified in two (16.67\%). Among the protozoa, Cystoisospora spp. were found in one sample (8.33\%). Among the household cats, we identified a combination of different genera-Ancylostoma sp. plus Uncinaria sp.-in only one case (8.33\%).

Table 5 shows the species infecting the shelter cats. As in the household cats, helminths predominated, Ancylostoma spp. being identified in 55 (29.41\%) of the 187 infected shelter cats, followed by Toxocara spp., in 31 (16.58\%). The only protozoa infecting the shelter cats were those of the genus Cystoisospora, which were identified in isolation in 49 cats (26.20\%) and with or without helminths in 77 (41.18\%). The prevalence of monoparasitism among the shelter cats was $72.19 \%$. Among the shelter cats with multiparasitism, the parasite combination most commonly observed was Ancylostoma spp. plus Toxocara spp., which was seen in $22(11.76 \%)$ of the 187 infected cats, followed by Cystoisospora plus Toxocara spp., seen in 15 (8.02\%). 
Table 4. Endoparasite infection among household cats in the city of Rio de Janeiro, Brazil.

\begin{tabular}{|c|c|c|c|c|c|c|c|c|c|c|c|c|c|}
\hline \multirow{4}{*}{ Endoparasite } & \multicolumn{2}{|c|}{ Sex } & \multicolumn{5}{|c|}{ Life stage } & \multicolumn{2}{|c|}{ Lifestyle } & \multicolumn{3}{|c|}{ Zone of the city } & \multirow{3}{*}{ Total } \\
\hline & M & $\mathbf{F}$ & Ki & Ju & $\operatorname{Pr}$ & Ma & Un & C & S-C & $\mathbf{N}$ & S & w & \\
\hline & $(n=26)$ & $(n=31)$ & $(n=5)$ & $(n=17)$ & $(n=13)$ & $(n=9)$ & $(n=10)$ & $(n=36)$ & $(n=21)$ & $(n=5)$ & $(n=1)$ & $(n=51)$ & \\
\hline & $n(\%)$ & $n(\%)$ & $n(\%)$ & $n(\%)$ & $n(\%)$ & $n(\%)$ & $n(\%)$ & $n(\%)$ & $n(\%)$ & $n(\%)$ & $n(\%)$ & $n(\%)$ & $n(\%)$ \\
\hline Cystoisospora spp. & $1(14.28)$ & - & $1(50.0)$ & - & - & - & - & 1 (16.67) & - & $1(100)$ & - & - & $1(8.33)$ \\
\hline Toxocara spp. & $1(14.28)$ & $1(20.0)$ & - & $1(20.0)$ & $1(100)$ & - & - & - & $2(33.33)$ & - & - & $2(20.0)$ & $2(16.67)$ \\
\hline Ancylostoma spp. & $2(28.57)$ & $1(20.0)$ & - & - & - & $1(100)$ & $2(66.67)$ & $2(33.33)$ & $1(16.67)$ & - & - & $3(30.0)$ & $3(25.0)$ \\
\hline Dipylidium caninum & $1(14.28)$ & $1(20.0)$ & $1(50.0)$ & $1(20.0)$ & - & - & - & $1(16.67)$ & $1(16.67)$ & - & - & $2(20.0)$ & $2(16.67)$ \\
\hline $\begin{array}{l}\text { Uncinaria spp. + } \\
\text { Ancylostoma spp. }\end{array}$ & $1(14.28)$ & - & - & $1(20.0)$ & - & - & - & - & $1(16.67)$ & - & $1(100)$ & - & $1(8.33)$ \\
\hline Strongyloides spp. & $1(14.28)$ & $2(40.0)$ & - & $2(40.0)$ & - & - & 1 (33.33) & 2 (33.33) & $1(16.67)$ & - & - & $3(30.0)$ & $3(25.0)$ \\
\hline Total & $7(26.92)$ & $5(16.13)$ & $2(40)$ & $5(29.41)$ & $1(7.69)$ & $1(11.11)$ & $3(30.0)$ & $6(16.67)$ & $6(28.57)$ & $1(20)$ & $1(100)$ & $10(19.61)$ & $12(100)$ \\
\hline
\end{tabular}

M: male; F: female; Ki: kitten; Ju: junior; Pr: prime; Ma: mature; Un: undetermined; C: confined; S-C: semi-confined; N: northern; S: southern; W: western. 
Table 5. Endoparasite infection among shelter cats in the city of Rio de Janeiro, Brazil.

\begin{tabular}{|c|c|c|c|c|c|c|c|c|c|c|c|c|c|c|c|c|c|}
\hline \multirow{4}{*}{ Endoparasite } & \multicolumn{2}{|c|}{ Sex } & \multicolumn{7}{|c|}{ Life stage } & \multicolumn{3}{|c|}{ Lifestyle } & \multicolumn{4}{|c|}{ Zone of the city } & \multirow{3}{*}{ Total } \\
\hline & M & $\mathbf{F}$ & $\mathbf{K i}$ & Ju & $\mathrm{Pr}$ & Ma & Se & Ge & Un & C & S-C & F-R & $\mathbf{N}$ & $\mathbf{s}$ & w & D & \\
\hline & $(n=162)$ & $(n=174)$ & $(n=155)$ & $(n=87)$ & $(n=64)$ & $(n=4)$ & $(n=3)$ & $(n=1)$ & $(n=22)$ & $(n=90)$ & $(n=38)$ & $(n=208)$ & $(n=81)$ & $(n=159)$ & $(n=45)$ & $(n=51)$ & \\
\hline & $n(\%)$ & $n(\%)$ & $n(\%)$ & $n(\%)$ & $n(\%)$ & $n(\%)$ & $n(\%)$ & $n(\%)$ & $n(\%)$ & $n(\%)$ & $n(\%)$ & $n(\%)$ & $n(\%)$ & $n(\%)$ & $n(\%)$ & $n(\%)$ & $n(\%)$ \\
\hline $\begin{array}{c}\text { Cystoisospora } \\
\text { spp. }\end{array}$ & $14(16.67)$ & 35 (33.98) & $38(38.77)$ & $3(7.14)$ & $4(12.90)$ & $1(50.0)$ & $1(100.0)$ & - & $2(16.67)$ & $6(16.67)$ & $2(10.0)$ & $41(31.30)$ & $12(24.0)$ & $19(20.0)$ & $8(50.0)$ & $10(38.46)$ & $\begin{array}{c}49 \\
(26.20)\end{array}$ \\
\hline Toxocara spp. & $12(14.28)$ & $19(18.45)$ & $15(15.31)$ & $9(21.43)$ & $5(16.13)$ & $1(50.0)$ & - & - & $1(8.33)$ & $12(33.33)$ & $2(10.0)$ & $17(12.98)$ & $6(12.0)$ & $24(25.26)$ & - & $1(3.85)$ & $\begin{array}{c}31 \\
(16.58)\end{array}$ \\
\hline $\begin{array}{l}\text { Ancylostoma } \\
\text { spp. }\end{array}$ & $28(33.33)$ & $27(26.21)$ & $14(14.29)$ & $18(42.86)$ & $17(54.84)$ & - & - & $1(100.0)$ & $5(41.67)$ & $8(22.22)$ & $10(50.0)$ & $37(28.24)$ & $17(34.0)$ & $24(25.26)$ & $5(31.25)$ & $9(34.61)$ & $\begin{array}{c}55 \\
(29.41)\end{array}$ \\
\hline $\begin{array}{c}\text { Dipylidium } \\
\text { caninum + } \\
\text { Toxocara spp. } \\
\text { Cystoisospora }\end{array}$ & $1(1.19)$ & - & - & $1(2.38)$ & - & - & - & - & - & - & $1(5.00)$ & - & $1(2.0)$ & - & - & - & $1(0.53)$ \\
\hline $\begin{array}{c}\text { spp. + Toxocara } \\
\text { spp. } \\
\text { Cystoisospora }\end{array}$ & $9(10.71)$ & $6(5.82)$ & $12(12.24)$ & $3(7.14)$ & - & - & - & - & - & $2(5.56)$ & - & $13(9.92)$ & $4(8.0)$ & $11(11.58)$ & - & - & $15(8.02)$ \\
\hline $\begin{array}{l}\text { spp. + } \\
\text { Ancylostoma } \\
\text { spp. }\end{array}$ & $4(4.76)$ & $3(2.91)$ & $3(3.06)$ & $2(4.76)$ & $1(3.23)$ & - & - & - & - & - & $2(10.0)$ & $5(3.82)$ & $1(2.0)$ & $2(2.10)$ & - & $4(15.38)$ & $7(3.74)$ \\
\hline $\begin{array}{l}\text { Dipylidium } \\
\text { caninum + } \\
\text { Ancylostoma } \\
\text { spp. }\end{array}$ & $1(1.19)$ & - & $1(1.02)$ & - & - & - & - & - & - & - & $1(5.00)$ & - & $1(2.0)$ & - & - & - & $1(0.53)$ \\
\hline $\begin{array}{c}\text { Ancylostoma } \\
\text { spp.+ Toxocara } \\
\text { spp. } \\
\text { Cystoisospora }\end{array}$ & 12 (14.28) & $10(9.71)$ & $12(12.24)$ & $4(9.52)$ & $4(12.90)$ & - & - & - & $2(16.67)$ & $8(22.22)$ & $1(5.00)$ & $13(9.92)$ & $5(10.0)$ & $13(13.68)$ & $3(18.75)$ & $1(3.85)$ & $\begin{array}{c}22 \\
(11.76)\end{array}$ \\
\hline $\begin{array}{c}\text { spp. }+ \text { Toxocara } \\
\text { spp.+ } \\
\text { Ancylostoma }\end{array}$ & $3(3.57)$ & $3(2.91)$ & $4(4.08)$ & $1(2.38)$ & - & - & - & - & $1(8.33)$ & - & $1(5.00)$ & $5(3.82)$ & $3(6.0)$ & $2(2.10)$ & - & $1(3.85)$ & $6(3.21)$ \\
\hline $\begin{array}{l}\text { spp. } \\
\text { Total }\end{array}$ & $84(51.85)$ & $\begin{array}{c}103 \\
(59.19)\end{array}$ & $98(63.22)$ & $42(48.27)$ & $31(48.44)$ & $2(50)$ & $1(33.33)$ & $1(100)$ & $12(54.54)$ & $36(40)$ & $20(52.63)$ & $\begin{array}{c}131 \\
(62.98)^{*}\end{array}$ & $50(61.73)$ & $95(59.75)$ & $16(35.56)$ & $26(50.98)$ & $187(100)$ \\
\hline
\end{tabular}

M: male; F: female; Ki: kitten; Ju: junior; Pr: prime; Ma: mature; Se: senior; Ge: geriatric; Un: undetermined; C: confined; S-C: semi-confined; F-R: free-roaming; N: northern; S: southern;

W: western; D: downtown. * $p \leq 0.05$ vs. the confined and semi-confined lifestyles. None of the samples tested positive for $A$. abstrusus. 


\section{Discussion}

The overall prevalence of endoparasite infection among the cats evaluated in the present study was $50.64 \%$. In keeping with the epidemiological patterns of endoparasite infections, many of the cats in our sample had outdoor access, increasing the risk of exposure to parasites (Palmer et al., 2008). In addition, anthelmintic treatment in cats is rarely based on prior fecal examination and diagnosis, and the efficacy of the treatment administered is seldom confirmed by post-treatment testing (Nareaho et al., 2012).

The prevalence of endoparasite infection found for household cats in the present study $(21.05 \%)$ is higher than that reported in previous studies, such as the $6.0 \%$ reported in a study conducted in Canada (Hoopes et al., 2015) and the $10.1 \%$ reported in a study conducted in Japan (Itoh et al., 2012), albeit lower than the 22.8\%,33.2\%, and 39.6\%, respectively, reported in studies conducted in Germany (Barutzki \& Schaper, 2013), Greece (Kostopoulou et al., 2017), and Hungary (Capari et al., 2013). Among other studies of household cats in Brazil, one conducted in the state of Pernambuco found the prevalence of endoparasite infection to be $65.31 \%$ (Monteiro et al., 2016), much higher than in the present study, whereas studies conducted in the state of São Paulo have reported rates ranging from 18.1\% (Gennari et al., 2016) to 31.5\% (Funada et al., 2007) and a study conducted in the state of Paraná reported a prevalence of $43.91 \%$ (Ferreira et al., 2013). In another study of household and shelter cats in the metropolitan area of Rio de Janeiro (Serra et al., 2003), the overall prevalence of endoparasite infection was reported to be $29.2 \%$, similar to the $21.05 \%$ found only among the household cats in the present study. The disparity in these data might be the result of different levels of preventive veterinary care and of the use of appropriate antiparasitic drugs (Matos et al., 2015). Likewise, many cat owners believe that indoor cats are not exposed to parasites and therefore do not take the appropriate preventive measures (Diakou et al., 2017).

Pereira et al. (2017) found the prevalence of endoparasite infection among shelter cats in the city of Rio de Janeiro to be $49.5 \%$, comparable to the $50.64 \%$ found in the present study. Serra et al. (2003) studied stray cats in the metropolitan area of Rio de Janeiro and reported a $63.4 \%$ prevalence of endoparasite infection. Our finding that such infection was more common among shelter cats than among household cats, as was multiparasitism, is likely attributable to the immunosuppressive effects of environmental stress, close contact with infected cats and their excreta, and environmental contamination with feces from parasitized cats (Palmer et al., 2008).

In the present study, there was no significant sex-related difference in the prevalence of endoparasite infection, for household or shelter cats, as has been reported in other studies (Itoh et al., 2012; Ramos et al., 2013; Knaus et al., 2014; Yang \& Liang, 2015; Kostopoulou et al., 2017; Pereira et al., 2017). However, the prevalence of endoparasite infection was significantly higher among male and female shelter cats than among household cats of the same sex. That might indicate that males and females are equally exposed to endoparasites in these environments. Therefore, the type of environment in which the cats lived was a determinant of the risk of infection, whereas sex was not. In shelters, there is usually a high-density population of cats, which leads to stress, more difficulty in maintaining hygiene, and a higher probability of exposure to parasites (Esccap, 2018).

In the present study, the predominant life stages among household cats were junior, prime, and mature, which showed significant differences in relation to the other stages, whereas the kitten life stage was significantly predominant among the shelter cats. The latter might be due to the abandonment of unwanted kittens and the rescue of pregnant or breastfeeding queens. For that matter, educational campaigns on the importance of neutering should be implemented to avoid unwanted reproduction, thereby reducing the spread of parasites. When analyzed by life stage, the prevalence of 
endoparasite infection did not differ significantly between the household and shelter cats, with the exception of the prime stage, the prevalence being significantly higher among the shelter primes than among the household primes. It is likely that the shelter primes were more experienced in hunting (Zottler et al., 2019), therefore having greater exposure to infected paratenic/intermediate hosts, than were the household primes. In a study of household cats in Japan, conducted by Itoh et al. (2012), the prevalence of endoparasite infection was found to be significantly higher among kittens than among older cats. Younger animals are more susceptible to such infection because their immune system is not yet fully matured and because they can be infected by their mothers through vertical transmission during pregnancy and breastfeeding (Bowman, 2014). However, in the present study, we found no statistical difference between kittens and older cats in terms of the prevalence of endoparasite infection, neither among the household cats nor among the shelter cats. When a cat is adopted or introduced into a shelter, one of the first routine procedures is typically the prophylactic use of antiparasitic drugs, which are easily obtained in Brazil. Therefore, there is no information concerning antiparasitic treatment among the cats evaluated in the present study.

Among the shelter cats in our study sample, lifestyle influenced the prevalence of parasitism. The prevalence of endoparasite infection was significantly higher in the shelter cats with a confined lifestyle than in their household counterparts. The former had probably never received any preventive veterinary care and were exposed to a more highly contaminated environment, as well as to the stress of living in such close proximity to other cats. That forced proximity runs contrary to the nature of cats as solitary hunters (Ellis et al., 2013) and might therefore expose them to a wider range of parasites. Ourfinding that the prevalence of endoparasite infection did not differ between household and shelter cats with a semi-confined lifestyle might be explained by those cats being less exposed to contaminated areas and a lower density of animals in their surroundings.

Hookworms and Toxocara spp. were the most prevalent helminths detected in stool samples of household and shelter cats, similarly to other studies from Rio de Janeiro (Serra et al., 2003; Pereira et al., 2017). These parasites can infect cats from all life stages and can cause environmental contamination (Lee et al., 2010), as the Toxocara eggs can survive patently in the environment for years and may be an important source of infection (Villeneuve et al., 2015), which is particularly important due to its zoonotic potential, especially among children (Fisher, 2003; Yang \& Liang, 2015).

Among humans, there is an association between socioeconomic conditions and endoparasite infection (Speich et al., 2016). Although some samples were obtained from neighborhoods on the periphery of the city of Rio de Janeiro, where social and environmental conditions are poorer (Faria et al., 2017), especially in the western zone, the zone of the city had no significant effect on the prevalence of endoparasite infection among the household cats. The fact that we obtained the samples by convenience (i.e., from cat owners or shelters that agreed to participate in the study) probably limited our assessment of the actual prevalence in each zone.

Studies evaluating the presence of stages of $A$. abstrusus in stool samples of cats in the city of Rio de Janeiro have shown a decrease in the prevalence of $A$. abstrusus over the years. Souza-Dantas (2006) identified first-stage A. abstrusus larvae in $3.7 \%$ of stool samples collected from cats in the city. As previously mentioned, no stages of $A$. abstrusus were identified in the present study, although many of the samples analyzed were obtained from recently free-roaming cats with possible access to intermediate hosts such as gastropods. In a study conducted in the southern region of Brazil, Ehlers et al. (2013) reported a significant decrease in the prevalence of aelurostrongylosis from $45.8 \%$ in 2008 to $5.0 \%$ in 2009. Traversa et al. (2010) reported the emergence of aelurostrongylosis in Europe, probably triggered by climate change. It is known that global warming favors the dispersal and spread of intermediate hosts and parasites (Root et al., 2003), 
consequently increasing the prevalence of parasitism. However, a decrease in the prevalence of aelurostrongylosis was observed in the city of Rio de Janeiro. This discrepancy could be due to the seasonality of the A. abstrusus, whereas warmer temperatures could benefit life forms such as intestinal parasites (Okoye et al., 2014), or to cyclical occurrence of $A$. abstrusus in the environment. Nevertheless, this remains speculative and merits further study.

The present study demonstrated different levels of parasitism and multiparasitism in cats in the city of Rio de Janeiro. Many samples were positive for different life forms of parasites. These data underscore the importance of preventive veterinary care and routine coproparasitologic analysis for shelter and household cats, even when they are kept exclusively indoors, which will allow targeted treatment to avoid the spread of parasites, especially those with zoonotic potential.

\section{Acknowledgements}

This study was financed in part by the Brazilian Coordenação de Aperfeiçoamento de Pessoal de Nível Superior (CAPES, Office for the Advancement of Higher Education; Grant no. 001).

\section{References}

Barutzki D, Schaper R. Occurrence and regional distribution of Aelurostrongylus abstrusus in cats in Germany. Parasitol Res 2013; 112(2): 855-861. http://dx.doi.org/10.1007/s00436-012-3207-0. PMid:23239090.

Blaszkowska J, Wojcik A, Kurnatowski P, Szwabe K. Geohelminth egg contamination of children's play areas in the city of Lodz (Poland). Vet Parasitol 2013; 192(1-3): 228-233. http://dx.doi.org/10.1016/j.vetpar.2012.09.033. PMid:23084538.

Bowman DD, Hendrix CM, Lindsay DS, Barr SC. The Cestodes. In: Bowman DD, Hendrix CM, Lindsay DS, Barr SC. Feline Clinical Parasitology. Iowa: Iowa State University Press; 2002a. p. 183-232. https://doi.org/10.1002/9780470376805.ch3.

Bowman DD, Hendrix CM, Lindsay DS, Barr SC. The Protozoa. In: Bowman DD, Hendrix CM, Lindsay DS, Barr SC. Feline Clinical Parasitology. Iowa: lowa State University Press; 2002b. p. 3-81. http://dx.doi.org/10.1002/9780470376805.ch1.

Bowman DD, Montgomery SP, Zajac AM, Eberhard ML, Kazacos KR. Hookworms of dogs and cats as agents of cutaneous larva migrans. Trends Parasitol 2010; 26(4): 162-167. http://dx.doi.org/10.1016/j.pt.2010.01.005. PMid:20189454.

Bowman DD. Georgis' parasitology for veterinarians. 10th ed. St. Louis, Missouri: Elsevier, Saunders; 2014.

Capari B, Hamel D, Visser M, Winter R, Pfister K, Rehbein S. Parasitic infections of domestic cats, Felis catus, in western Hungary. Vet Parasitol 2013; 192(1-3): 33-42. https://doi.org/10.1016/j.vetpar.2012.11.011

Centers for Disease Control and Prevention - CDC. Epi Info [online]. Atlanta: CDC; 2011 [cited 2018 Jan 10]. Available from: http://www.cdc.gov/epiinfo/por/pt_index.html

Coelho WMD, Amarante AFT, Soutello RVG, Meireles MV, Bresciani KDS. Occurrence of gastrointestinal parasites in fecal samples of cats in Andradina City, São Paulo. Rev Bras Parasitol Vet 2009; 18(2): 46-49. http://dx.doi.org/10.4322/rbpv.01802010. PMid:19602317.

Diakou A, Sofroniou D, Di Cesare A, Kokkinos P, Traversa D. Occurrence and zoonotic potential of endoparasites in cats of Cyprus and a new distribution area for Troglostrongylus brevior. Parasitol Res 2017; 116(12): 3429-3435. http://dx.doi.org/10.1007/s00436-017-5651-3. PMid:29034414.

Ehlers A, Mattos MJT, Marques SMT. Prevalence of Aelurostrongylus abstrusus (Nematoda, Srongylida) in cats from Porto Alegre, Rio Grande do Sul. Rev FZVA 2013; 19(1): 97-104.

Ellis SLH, Rodan I, Carney HC, Heath S, Rochlitz I, Shearburn LD, et al. AAFP and ISFM feline environmental needs guidelines. J Feline Med Surg 2013; 15(3): 219-230. http://dx.doi.org/10.1177/1098612X13477537. PMid:23422366. 
Elsheikha HM, Schnyder M, Traversa D, Di Cesare A, Wright I, Lacher DW. Updates on feline aelurostrongylosis and research priorities for the next decade. Parasit Vectors 2016; 9(1): 389. http://dx.doi.org/10.1186/s13071-016-1671-6. PMid:27387914.

European Scientific Counsel Companion Animal Parasites - ESCCAP. GL1: Worm Control in Dogs and Cats [online]. United Kingdom: ESCCAP; 2018 [cited 2018 Dec 1]. Available from: https://www.esccap.org/page/GL1+Worm+Control+in+Dogs+and+Cats/25/\#.XRQQ_

Faria CP, Zanini GM, Dias GS, Silva S, Freitas MB, Almendra R, et al. Geospatial distribution of intestinal parasitic infections in Rio de Janeiro (Brazil) and its association with social determinants. PLoS Neg/ Trop Dis 2017; 11(3): 1-21. http://dx.doi.org/10.1371/journal.pntd.0005445. PMid:28273080.

Ferreira AMR, Souza-Dantas LM, Labarthe N. Registro de um caso de Aelurostrongylus abstrusus (Railliet, 1898) em um gato doméstico no Rio de Janeiro, RJ. Braz J Vet Res Anim Sci 2007; 44(1): 24-26. http://dx.doi.org/10.11606/issn.1678-4456.bjvras.2007.26656.

Ferreira FP, Dias RCF, Martins TA, Constantino C, Pasquali AKS, Vidotto O, et al. Frequência de parasitas gastrointestinais em cães e gatos do município de Londrina, PR, com enfoque em saúde pública. Semina: Ciênc Agrár 2013; 34(2): 3851-3858. http://dx.doi.org/10.5433/16790359.2013v34n6Supl2p3851.

Fisher M. Toxocara cati, an underestimated zoonotic agent. Trends Parasitol 2003; 19(4): 167-170. http://dx.doi.org/10.1016/S1471-4922(03)00027-8. PMid:12689646.

Funada MR, Pena HFJ, Soares RM, Amaku M, Gennari SM. Freqüência de parasitos gastrintestinais em cães e gatos atendidos em hospital-escola veterinário da cidade de São Paulo. Arq Bras Med Vet Zootec 2007; 59(5): 1338-1340. http://dx.doi.org/10.1590/S0102-09352007000500038.

Gennari SM, Ferreira JIGS, Pena HFJ, Labruna MB, Azevedo SS. Frequency of gastrointestinal parasites in cats seen at the University of São Paulo Veterinary Hospital, Brazil. Rev Bras Parasitol Vet 2016; 25(4): 423-428. http://dx.doi.org/10.1590/s1984-29612016082. PMid:27925073.

Hoopes J, Hill JE, Polley L, Fernando C, Wagner B, Schurer J, et al. Enteric parasites of free-roaming, owned, and rural cats in prairie regions of Canada. Can Vet J 2015; 56(5): 495-501. PMid:25969584.

Hotez PJ. Neglected infections of poverty in the United States of America. PLoS Neg/ Trop Dis 2008; 2(6): e256. http://dx.doi.org/10.1371/journal.pntd.0000256. PMid:18575621.

Hoyumpa Vogt A, Rodan I, Brown M, Brown S, Buffington CAT, Larue Forman MJ, et al. AAFP-AAHA: Feline life stage guidelines. J Feline Med Surg 2010; 12(1): 43-54. http://dx.doi.org/10.1016/j.jfms.2009.12.006. PMid:20123486.

Ito Y, Itoh N, Kimura Y, Kanai K. Prevalence of intestinal parasites in breeding cattery cats in Japan. J Feline Med Surg 2016; 18(10): 834-837. http://dx.doi.org/10.1177/1098612X15597023. PMid:26208865.

Itoh N, Ikegami H, Takagi M, Ito Y, Kanai K, Chikazawa S, et al. Prevalence of intestinal parasites in private-household cats in Japan. J Feline Med Surg 2012; 14(6): 436-439. http://dx.doi.org/10.1177/1098612X12443633. PMid:22467797.

Jiang P, Zhang X, Liu RD, Wang ZQ, Cui J. A human case of zoonotic dog tapeworm, Dipylidium caninum (Eucestoda: Dilepidiidae), in China. Korean J Parasitol 2017; 55(1): 61-64. http://dx.doi.org/10.3347/kjp.2017.55.1.61. PMid:28285500.

Knaus M, Rapti D, Shukullari E, Kusi I, Postoli R, Xhaxhiu D, et al. Characterisation of ecto- and endoparasites in domestic cats from Tirana, Albania. Parasitol Res 2014; 113(9): 3361-3371. http://dx.doi.org/10.1007/s00436-014-3999-1. PMid:24994454.

Kostopoulou D, Claerebout E, Arvanitis D, Ligda P, Voutzourakis N, Casaert S, et al. Abundance, zoonotic potential and risk factors of intestinal parasitism amongst dog and cat populations: the scenario of Crete, Greece. Parasit Vectors 2017; 10(1): 43. http://dx.doi.org/10.1186/s13071-0171989-8. PMid:28122583.

Lee ACY, Schantz PM, Kazacos KR, Montgomery SP, Bowman DD. Epidemiologic and zoonotic aspects of ascarid infections in dogs and cats. Trends Parasitol 2010; 26(4): 155-161. http://dx.doi.org/10.1016/j.pt.2010.01.002. PMid:20172762.

Matchock RL. Pet ownership and physical health. Curr Opin Psychiatry 2015; 28(5): 386-392. http://dx.doi.org/10.1097/YCO.0000000000000183. PMid:26164613. 
Matos M, Alho AM, Owen SP, Nunes T, Madeira de Carvalho L. Parasite control practices and public perception of parasitic diseases: A survey of dog and cat owners. Prev Vet Med 2015; 122(1-2): 174-180. http://dx.doi.org/10.1016/j.prevetmed.2015.09.006. PMid:26404913.

McNicholas J, Gilbey A, Rennie A, Ahmedzai S, Dono J-A, Ormerod E. Pet ownership and human health: a brief review of evidence and issues. BMJ 2005; 331(7527): 1252-1254. http://dx.doi.org/10.1136/bmj.331.7527.1252. PMid:16308387.

Monteiro MFM, Ramos RAN, Calado AMC, Lima VFS, Ramos ICN, Tenório RFL, et al. Gastrointestinal parasites of cats in Brazil: frequency and zoonotic risk. Rev Bras Parasitol Vet 2016; 25(2): 254257. http://dx.doi.org/10.1590/S1984-29612016019. PMid:27096530.

Nareaho A, Puomio J, Saarinen K, Jokelainen P, Juselius T, Sukura A. Feline intestinal parasites in Finland: prevalence, risk factors and anthelmintic treatment practices. J Feline Med Surg 2012; 14(6): 378-383. http://dx.doi.org/10.1177/1098612X12439257. PMid:22328587.

Okoye IC, Obiezue NR, Okoh FN, Amadi EC. Descriptive epidemiology and seasonality of intestinal parasites of cats in Southeast Nigeria. Comp Clin Pathol 2014; 23(4): 999-1005. http://dx.doi.org/10.1007/s00580-013-1734-4.

Palmer CS, Thompson RCA, Traub RJ, Rees R, Robertson ID. National study of the gastrointestinal parasites of dogs and cats in Australia. Vet Parasitol 2008; 151(2-4): 181-190. http://dx.doi.org/10.1016/j.vetpar.2007.10.015. PMid:18055119.

Pereira PF, Barbosa AS, Moura APP, Vasconcellos ML, Uchôa CMA, Bastos OMP, et al. Gastrointestinal parasites in stray and shelter cats in the municipality of Rio de Janeiro, Brazil. Rev Bras Parasitol Vet 2017; 26(3): 383-388. http://dx.doi.org/10.1590/s1984-29612017024. PMid:28678896.

Petry G, Kruedewagen E, Kampkoetter A, Krieger K. Efficacy of emodepside/toltrazuril suspension (Procox ®oral suspension for dogs) against mixed experimental /sospora felis//sospora rivolta infection in cats. Parasitol Res 2011;109(S1 Suppl 1): S29-S36. http://dx.doi.org/10.1007/s00436011-2400-x. PMid:21739373.

Ramos DGS, Scheremeta RGAC, Oliveira ACS, Sinkoc AL, Pacheco RC. Survey of helminth parasites of cats from the metropolitan area of Cuiabá, Mato Grosso, Brazil. Rev Bras Parasitol Vet 2013; 22(2): 201-206. http://dx.doi.org/10.1590/S1984-29612013000200040. PMid:23856737.

Root TL, Price JT, Hall KR, Schneider SH, Rosenzweig C, Pounds JA. Fingerprints of global warming on wild animals and plants. Nature 2003; 421(6918): 57-60. http://dx.doi.org/10.1038/nature01333. PMid:12511952.

Scofield A, Madureira RC, Oliveira CJF, Guedes DS Jr, Soares CO, Fonseca AH. Diagnóstico pós-morte de Aelurostrongylus abstrusus e caracterização morfométrica de ovos e mórulas por meio de histologia e impressão de tecido. Cienc Rural 2005; 35(4): 952-955. http://dx.doi.org/10.1590/S0103-84782005000400036.

Serra CMB, Uchoa CMA, Coimbra RA. Parasitological study with faecal samples of stray and domiciliated cats (Felis catus domesticus) from the Metropolitan Area of Rio de Janeiro, Brazil. Rev Soc Bras Med Trop 2003; 36(3): 331-334. http://dx.doi.org/10.1590/S0037-86822003000300003. PMid:12908032.

Sheather AL. The detection of intestinal protozoa and mange parasites by a flotation technique. $J$ Comp Pathol Ther 1923; 36: 266-275. http://dx.doi.org/10.1016/S0368-1742(23)80052-2.

Souza-Dantas LM. Prevalência da infecção por Aelurostrongylus abstrusus (Railliet, 1858) Cameron, 1927 em gatos domésticos (Felis catus Linnaeus, 1758) da Região Metropolitana do Rio de Janeiro [dissertation]. Rio de Janeiro: Universidade Federal Fluminense; 2006.

Speich B, Croll D, Furst T, Utzinger J, Keiser J. Effect of sanitation and water treatment on intestinal protozoa infection: a systematic review and meta-analysis. Lancet Infect Dis 2016; 16(1): 87-99. http://dx.doi.org/10.1016/S1473-3099(15)00349-7. PMid:26404667.

Traversa D, Di Cesare A, Conboy G. Canine and feline cardiopulmonary parasitic nematodes in Europe: Emerging and underestimated. Parasit Vectors 2010; 3(1): 62. http://dx.doi.org/10.1186/1756-3305-3-62. PMid:20653938.

Traversa D, Di Cesare A. Feline lungworms: What a dilemma. Trends Parasito/ 2013; 29(9): 423-430. http://dx.doi.org/10.1016/j.pt.2013.07.004. PMid:23928099. 
Traversa D, Guglielmini C. Feline aelurostrongylosis and canine angiostrongylosis: A challenging diagnosis for two emerging verminous pneumonia infections. Vet Parasitol 2008; 157(3-4): $163-$ 174. http://dx.doi.org/10.1016/j.vetpar.2008.07.020. PMid:18775603.

Villeneuve A, Polley L, Jenkins E, Schurer J, Gilleard J, Kutz S, et al. Parasite prevalence in fecal samples from shelter dogs and cats across the Canadian provinces. Parasit Vectors 2015; 8(1): 281. http://dx.doi.org/10.1186/s13071-015-0870-x. PMid:26013283.

Yang Y, Liang $\mathrm{H}$. Prevalence and risk factors of intestinal parasites in cats from China. BioMed Res Int 2015; 2015: 1-5. http://dx.doi.org/10.1155/2015/967238

Zottler EM, Bieri M, Basso W, Schnyder M. Intestinal parasitesandlungworms in stray, shelter and privately-owned cats of Switzerland. Parasitol Int 2019; 69: 75-81.

https://doi.org/10.1016/j.parint.2018.12.005 